\title{
The Qur'an and the Creation of Universes (A Study on Ibn Arabi's Thought)
}

\author{
$1^{\text {st }}$ Muhamad Firdaus ${ }^{1}, 2^{\text {nd }}$ Yusuf Rahman and ${ }^{2}, 3^{\text {rd }}$ Alvin Noor Sahab Rizal ${ }^{1}, 4^{\text {th }}$ Nadhif \\ Muhammad Mumtaz ${ }^{1}$ \\ \{firdausm301@gmail.com¹, yusuf.rahman@uinjkt.ac.id¹, alvin.noor18@mhs.uinjkt.ac.id ${ }^{1}$ \} \\ UIN Syarif Hidayatullah, Islamic Studies Department, ${ }^{1}$ UIN Syarif Hidayatullah, Faculty of Ushuluddin, \\ Jakarta, Indonesia ${ }^{2}$
}

\begin{abstract}
This article is discusses Ibn 'Arabi's interpretation of the concept of the creation of the universe. this figure was taken by the writer because he interpreted it symbolically about the verse of creation. The Qur'an has formulated a six-day creation process. The symbolic interpretation offered by Ibn 'Arabi might be a new thing in this study. This study aims to analyze the interpretation of Ibn 'Arabi in all of his books. analysis using Paul Ricoeur's hermeneutics. The method used is qualitative because research sources come from literature sources that refer to Creswell. The data from this study comes from all of Ibn 'Arabi's interpretations of the verses of the creation of the Universe the results of this study indicate that Ibn' Arabi in interpreting verses about the creation of the universe didn't touch the process and chronology at all.
\end{abstract}

Keywords: tafsir, Ibnu 'Arabi, hemeneutics, creation of universe.

\section{Introduction}

The discourse about the concept of the creation of the universe began very long ago, even that happened thousands of years ago BC. Precisely in the 6th century the birth of the first natural philosopher from Greece, namely Thales who was given a title by Aristotle as "The First Philosophers", and he was known by the Greeks as one of the hoi liepta soplioi or The Seven Wise and al-Hukania ' al-Sab'ah are seven wise people. Thales holds that the origin of nature is made of water, in contrast to the Greeks in general who believe in myths and superstitions.[1]

Then the development of that thought was continued by his student Anaximandros who was different from Thales in the process of creating nature. According to him, nature was created from one, but not water, and not something that can be observed by the five senses, which Anaximandros calls to Apeiron, something that is infinite and infinite [1].

Complementing the initial trio of philosophers who discussed the creation of nature, the final figure was Anaximenes who was a student of Anaximandros. This figure wants to combine the two previous theories, if Thales with something visible is water and Anaximandros with something invisible, only one and infinite again. So Anaximenes accepted the teachings of his teacher Anaximandros, but disagreed if the origin was something that cannot be forgotten. For him, the origin must be from the one and what appears, namely air [1]. 
After the era of ancient philosophers whose views were still very simple, long after that came the idea of the creation of nature in the era of scientists after the Renaissance. The first Steady State Theory theory was first put forward by Sir James Hopwood Jeans which appeared in 1928. In his book Astronomy and Cosmology that the creation of the universe took place continuously. So the centers of the nebula are the natural 'singular points' where the material of our universe comes from alien and special dimensions, so the points appear where the matter is created continuously. Then 20 years later this theory was developed by three cosmologists; Hermann Bondi, Sir Fred Hoyle, Thomas Gold who stated that although the universe continued to expand, the material was updated with new material, so that the area and size were still the same, unchanged. So the universe has no beginning and no end.

The second theory is the Big Bang which was first pioneered by Georges Lemaitre, so in 1922. At first, a scientist named Alexander Friedmann put forward the theory of Friedmann's equations which showed that the universe was expanding, it happened in 1922. Five years after that Lemaitre, based on his theory Friedmann suggested that the distance of the earth from the galaxy is very far and generally proportional to the red line, unfortunately, this discovery was better known two years after that, when Edwin Hubble put forward the theory. Lemaitre explained further, that the condition of the explosion was the contraction of the universe to a point called the "ancient atom" where space and time began. Then Stephen Hawking with his M-theory is based on quantum expectations, to produce the conclusion that the universe created by itself.

Finally, the Oscillation theory proposed by three people; Wolfgang M. Schmidt, Arno Allan Penzias, and Robert Woodrow Wilson. This theory is almost similar to the steady state, so the universe does not have a beginning and an end, only this theory recognizes the existence of a big bang and at some point, gravity will suck up again and reassemble at high densities with high temperatures as well, then booms occur again. it goes on and on.

The theories above are theories that were born from the Western tradition, from classical times to modern times. If related to Islam, in the Koran itself it has been explained the problem of the creation of nature that the universe is derived from nothing but from something that exists and in the process of its creation undergoes six stages or periods.

It is Ibn 'Arabi who has his interpretation with a Sufistic nuance so that he can offer a new interpretation that is different from the Qur'an because it dissects the meaning of the baținiyah which of course is not separate from the meaning of its birth. In his interpretation, it is not uncommon for him to use symbols and analogies that need to be dissected specifically, then a tool to dissect them with Paul Ricoeur's semiotics.

\section{Get to Know Ibn 'Arabi}

Ibn 'Arabi was born in 560-638 H / 1165-1234 H in Mursiya, Andalusia (now in Spanish territory). His father was a state official during the reign of Muhammad Ibn Sa'id Mardanish, ruler of Murcia. Besides that, his mother's uncle was the ruler of Tlemcen, Algeria, he was also close to the kings in his neighborhood. He and his family had moved to Seville because Murcia was attacked by Almohad (Al-Muwāhidīn) in 567 H / 1172 AD, in that area his father returned to a position as a government employee.[2]

When Ibn 'Arabi was 8 years old he started his formal schooling and under famous scholars, he studied the Qur'an and its interpretations, hadith, fiqh, theology and scholastic philosophy. In Seville, it became the center of Sufism and many famous Sufis lived. Because 
of his success in terms of education, he was appointed as Gurbernur's secretary and later married a pious woman named Maryam. Environmental factors, coupled with the support of his wife that he later became a Sufi, officially entered the Tarekat in 580/1184 when he was twenty years old.[3]

The scientific spirit of Ibn 'Arabi visited Sufis and scholars as far as Spain and North Africa, he even met the old philosopher of Aristotle, Ibn Rushd and had a scientific dialogue with him. In the dialogue, it contains the fundamental conflict between logical reasoning and the path of the gnostic imagination which ultimately divides Islamic thought into two branches. Although Ibn 'Arabi was still relatively young, in reality, he managed to defeat a senior philosopher. This is due to the breadth of the experience of mysticism Ibn 'Arabi who is also covered with philosophical thoughts that are very strict, he expresses his spiritual experience with the language of philosophy with a very intelligent.[3]

At the age of 38 years according to the calculation of the solar year, in $590 \mathrm{M} / 1193 \mathrm{H}$, Ibn 'Arabi began to leave the Iberian Peninsula. That year he went to Tunis to study with Ibn Qasi, he learned about 'taking off his shoes' on him. Ibn Qasi was a Sufi leader who carried out a rebellion in the al-Murābbitin Dynasty in the Algarve. The following year in 591 AD / 1194 AH he visited Fez, he also wrote the Book of al-Isra 'in 1197-98, one year after that he went to Kordova to attend the funeral of Ibn Rushd. In the same year, he moved to Almeria and wrote Mawaqi 'al-Nujūm.[3]

Due to unstable political stability, Ibn 'Arabi left Spain and North Africa. The departure brought blessings to Ibn 'Arabi, because if he were still in that place, what would have happened to Ibn Qasi also happened to him. He was killed in $546 \mathrm{AH}$, as well as Ibn Barrajan and Ibn 'Arif who died due to poisoning by Gurbernur North Africa and' Ali b. Yusuf died in prison for years.[4]

Ibn 'Arabi died on 22 Rabbis' al-Tsani 638 / November 1240 in Damascus. He was buried in Salihiyyah, foothills of Qāsiyūn in the northern part of the City of Damascus. The place is often visited by Muslims because they consider it to be purified by all the prophets, especially al-Khadir. The place became increasingly crowded because there was Ibn 'Arabi who was buried there[3]

\section{Regarding the Sufi Interpretation Debate}

Sufi interpretation since his birth, among his brothers (interpretation of bil ma'tsūr and bil riwāyah), he was the most controversial. Even Imam Suyuthi in his al-Itqān, he gave a very firm statement; "Sufi opinions about the Qur'an are not interpretations".[5] In line with this thirteenth-century hadith scholar named Ibn Shalah, in his fatwa which took a statement from Abu al-Hasan al-Wahidi (d. 1075), that if al-Sulami believed that the book he wrote, namely Haqā'iq Tafsir as interpretation means he has kufr. [6]

In his book, Ibn Shalah recounts a dialogue between a person requesting a fatwa and a shaykh, that the shaykh exemplifies the interpretation of the word pagan in Surah al-Baqarah verse 123; "O you who believe, you should fight the infidels around you ...". For the Sufis, the purpose of infidels in that verse is lust, so we are encouraged to fight lust, which is man's strongest enemy. But for the requestor of the fatwa the interpretation that comes out of the meaning of zāhir is punished wrongly. So it is very natural that Sufis can be punished by infidels if the meanings they interpret relate to the creed.[7] 
Ibn Taymiyyah also experienced a misunderstanding of this interpretation of ishāri, according to him this interpretation of ishäri is the same as the inner interpretation which rejects the interpretation of birth.[8] Indeed, this Sufi interpretation is identical to the bātiniyyah interpretation of the Isma'iliyyah al-Imamiyyah Shiite who was attributed to Jafar al-Ṣādiq and if glanced further it refers to Abdullah bin Maymūn al-Qadāh who lived in Kufa and died at $276 \mathrm{H}$ (died).[9] But in fact, Michael A. Sells notes that the first-period Sufi interpretation was the Sufi interpretation of Jafar al-Saadiq compiled by al-Sulami. This interpretation prepared by al-Sulami has a special discussion about the Shi'a, namely placing the family of the Prophet (Muhammad, Ali, Fatima, al-Hasan, and al-Husayn) in cosmic and mystical roles. Nevertheless, this interpretation of Jafar al-Șādiq is a very clear and clear Sufi interpretation of the early period. This work shows the influence of the mystical dimension on the method of interpreting the Qur'an. This characteristic is seen when the interpretation explains mystical themes such as self-annihilation (fana '), and eternity (baqā'), sometimes in starting the interpretation preceded by the sentence "Ja'far said," or "al-Șādiq said".[10]

Regarding this interpretation compiled by al-Sulami, Husain al-Zahabi commented that because of his birth in the early period of the development of the well-known interpretation and interpretation was the interpretation of bil ma'tsur, it is only natural for me to interpret this interpretation in the early days like Ibn Taymiyyah also doubts that interpretation. Even though the commentary sometimes mentions the hadith but because the sanad is not clear even to the hands of al-Sulami himself then still it is not considered valid.[11]

From the Orientalists, as Nicholson himself said that the composition of the Koran could not be a basis for Sufi teachings, so he borrowed the takwil syi'ah method to be able to justify their Sufi teachings.[12]

Sansan Ziaul Haq summarizes some scholars who tend to reject this Sufi interpretation, we see as Ignaz Goldziher who states that most Sufis generally interpret with symbolic mechanisms as a justification tool for notions that are following the core of the Qur'an and the Sunnah . Fazlur Rahman also participated in the rejection that Sufi interpretation is only a thin polish of foreign thought which is actually not compatible with the teachings of the Qur'an. alJabiri explains more broadly that the interpretation of isharri is an attempt at reconciliation with teachings and traditions outside of Islam, according to him the tools contained in this interpretation of ishāri have actually been used by many Gnostic schools in many traditions, Sufis only adopt this Gnostic takwil originating from the Hellenism tradition and the philosophy of mystic-hermeneutic which would later be used to subdue religious texts against their teachings, so that the sacred texts are full of gnostic nuances.[13]

From most academics who accept the interpretation of ishäri they argue that the meaning of ishäri does not necessarily eliminate the literal meaning, rather the meaning of 'inside' is born because it is derived from the meaning of 'outside'. Omaima Abū Bakar explained that the symbolic character was indeed natural in the Koran because the Koran itself contained revelations from a holy God and his limited nature would, of course, risk multiplicity of meaning. So the internal charge is closely related to the external charge, and vice versa, both have a vertical relationship and do not negate each other.[14]

Schimmel further explained that these Sufi hermeneutics had a level, from simple verbal interpretations to symbolic and allegorical interpretations which in essence the Sufi interpretation models did not deny the meaning of being born from the Qur'an. The initial stigma of the scholars is that Sufis often abandon the meaning of being born, no longer cares about aspects of basic rules in Islam and as if jumping from the Shari'a directly to the essence to leave the formalities of worship. For Schimmel, it is too hasty to generalize all such Sufis because after all the Sufi Shari'a is a representation of the external Qur'an.[15] 
The Sufis themselves actually strongly reject the interpretation of the batiniyah which cuts down the exoteric meaning of the Qur'an. In connection with that problem, Imam Ghazali (d. $505 \mathrm{H}$ ) explained that the fundamental difference between Sufi ishāri interpretation and batini interpretation is, even though both of them want to express meaning outside the text, if the heart rejects the external meaning while the Sufi ishäri interpretation still holds firm to the external meaning of the Koran.[16] Campanini reinforces that Sufi interpretation is a process of evolution of interpretation towards deeper, more esoteric levels of meaning. In contrast to mystical-gnostic interpretations belonging to the Isma'iliyyah Shiite school which are not sourced from God. The esoteric Sufi interpretation comes from the knowledge of God that shows the spiritual path through the external text so that humans can understand the hidden secrets of faith and obedience.[17]

Sufi interpretation moves at an informal level, so it discusses worship from a legal and theological standpoint because it is formal legality. But what the Sufi interpretation is doing is the more spiritual appreciation of one's worship. If we remember the second hadith in the book al-Arba'in al-Nawawiyah, it will contain the hadith of the prophet which explains the definition of Islam, Imān, and Ihsān. The Ihsan concept that the prophet explained is "an ta'buda Allāh uses the meaning of tarāhu, fa in lam tarāh fainnahu yarāka" (you worship Allah as if you saw Allah, if you do not see it then make sure Allah sees you). The meaning implied from Ihsan was what later became the basis for this Sufi interpretation model.[7]

If we look at Maturidi's views on interpretation (w.333 H / 944 AD) then we will find that the interpretation was originally based on the orientation of bil ma'tsūr which only dwells on strong sources, namely the Koran or Hadith and the words of the friends, while the interpretation that is not based on it means categorized as a disgraceful interpretation. In other words, the initial development of the interpretive model was to use purely theorem naqli, the interpretation with the rational reasoning approach did not yet have a place at the time. They will use the transfer of meaning (ta'wil) from the meaning of zāhir only if in a situation that really forces to do so, such as when meeting with mutasyabihat verses or verses that intersect with the symptoms of anthropomorphism, solely in order to avoid tasybih to Allah or liken God to his creatures, closely related to theological elements. Some even totally reject the interpretation of bil ra'yi who reject ta'wil, their hope that the holiness of God from the likeness of his creatures will be maintained.[7]

\section{The Interpretation Model of Ibn Arabi}

Basically when a Sufi view a Qur'anic text he will see the multiplicity of meaning, as he sees the multiplicity of nature, microcosm and macrocosm. So a Sufi will not let the text in the Koran have only one meaning, one of the tools used by the Sufis is the ta'wil method that can bridge between the external world of the text and the spiritual meaning contained in it.[18] But the revelation of the meaning can only be obtained from someone who is truly clean in heart, namely the Sufis. Even though interpretations based on texts are born but spiritual meanings are always changing and shifting, following their respective Sufi experiences.[19]

Al-Qur'an is not a historical-linguistic book whose meaning is imprisoned by linguistic rules. Arabic is indeed the language used in the Koran, but it is only a piece of God's infinite expanse of God. Al-Qur'an is indeed the word of God, but there are verses in the form of reality called verses kauniyah. So for a Sufi, it will not explore the meaning of the Qur'an through language, but more than that, they directly listen to the words from God, while 
observing the reality of the universe contained in the text simultaneously.[20] The Sufi interpretation of the word of God is by listening to the word that manifests as the natural world while listening to the words of the soul from within which are both manifestations of the divine term.[13] After all, these Sufis were one step ahead of the exegete who only understood the Qur'an through linguistic principles.

According to Ibn 'Arabi, as quoted by Abū Zayd that the hierarchy of disclosure of meaning has four levels. First, 'âlam al-mulk wa al-shahādah, which is the physical-empirical nature. Second, 'ālam al-ghayb wa al-malaküt, which is the inner-spiritual realm. Third, ālam al-barzakh wal al-jabarüt, which is the intermediate realm, also called the boundary realm (älam al-hadd). Fourth, âlam al-asmā al-ilähiyyah, that is, the realm of God's names which is an absolute occult realm (al-barzakh wa al-kiyāl al-mutlaq), commonly called the final realm (älam al-mațla') so according to Ibn 'Arabi, in this world no one does not have the elements of the four ālam, must have zāhir, bāțin, hadd and mațla'. He further explained that what you have captured from the physical form is zāhir. What you perceive from the mental effect that governs his birth is bätin. What you distinguish with that other entity is hadd, according to the meaning of the term. Finally, when you come to His essence and successfully unveil the veil, that is what is called matla'.[20]

A simple example is a human being, the physical form of a human being is the body or body itself which can be absorbed by the senses, while the mind is the spirit that rules the entire body. Then the hadd is the difference between plants or animals, while the mațla 'is when the human has arrived at the final destination. From this logic, Ibn 'Arabi applied it to the text of the Qur'an. in fact, these four hierarchies have already been alluded to in the hadith of the Prophet:

$$
\begin{aligned}
& \text { أخرجه الفريابي من رواية الحسن مرسلا عن الرسول صلي الله عليه وسلم أنه قل :"لكل آية ظهر وبطن، } \\
& \text { "ولكل حرف حد، و كل حد مطلع }
\end{aligned}
$$

"Alfuryabi narrated the hasan mursal hadith from Rasulullah Saw. The Prophet said, "Every verse has the meaning of zahir and inner, every letter has a limit, and every boundary is raised."

In this case, Kristin Zahra Sands said that the symbolic language that is often used by Sufis is not a mere fantasy, but rather a symbolic meaning that is an objective reality born of a dialectical relationship between thought and order of the cosmos. It may indeed look like a metaphorical but actually, it is a description of what they experience in the spiritual world.[21]

Al-Harith al-Muhasibī has given restrictions for a Sufi in interpreting the Koran, which is not allowed to leave the rules that have been designed by scholars in the field of 'ulum alQur'ān and ușul fiqh such as the science of nāsikh and mansūkh, muḥkam and mutasyābih, uslüb taqdīm and ta'khìr, 'àm and khāsș and so forth. Based on what is said al-Muhasibī means that in interpreting the Qur'an, a Sufi must be based on the exoteric order of the Qur'an so that the Sufi does not interpret arbitrarily.[22]

Ibn 'Arabi himself has stated about his interpretation model in the Futūhāt alMakkiyyah that if in the Qur'an or hadith with a specific pronunciation, the first step taken is to interpret it with the meaning of what is following Arabic rules. Whereas if God uses pronunciations that are not in the sense of the language, but as sharia language terms such as the words prayer, wudu, zakat, and pilgrimage then what is determined is what is in accordance with shäri '(shari'ah lawmakers), all forms of command means to indicate obligation to do, as long as there are no indications that change to suggestions (al-nadb) or 
permissibility (al-ibāhah), as well as the form of prohibitions that make it can turn out to be unfavorable (al-karāhah).[23]

\section{Ibn 'Arabi's Interpretation of the Creation of Nature}

\subsection{Definition of Creation of Universes}

The term "nature" referred to here is a universe which in English is often referred to as "universe", and was translated into Arabic by Hans Wehr with ālam (عالم) [24] The term ālam only appears in the Qur'an always using the plural form (mulhaq jama 'mudzakkar salim) to ālamīn (عالمين) and is repeated 73 times in 30 letters. The details are; Surah al-Shu'ara twelve times, Surah al-A'raf seven times, Surah Ali 'Imran and al-An'am five times, Surah al-Baqarah and al-Ankabut four times, Surah al-Mā'idah, al-Anbiya ', al-Șāffāt and Ghāfir three times, and surah Yūnus, al-Naml, al-Jāthiyah and al-Taksir twice, and al-Fāhāah, Yūsuf, al-Hijr, alFurqān, al-Dukhān twice , al-Wāqi'ah, al-Ḥasyr, al-Qalam, al-Ḥāqat, al-Qaṣaṣ, al-Sajdah, alZumar, Fuș̦̣ilat, al-Zuhruf, al-Șād and Muṭaffifin each one time [25].

However, the term ālamīn differs from the term ālam which is defined by theologians and philosophers of Islam; theologians define that what is meant by allam is something other than Allah,[26] whereas according to Islamic philosophers it is a collection of distant beings composed of māddah (matter) and șūrah (forms) that exist on earth and sky.[27] Whereas Quraish Shihab states that why use the plural mudzakkar salim because it is used for something intelligent or approaching understanding, such as the angelic realm, human nature, natural nature of plant nature and others, but the term natural stone and natural soil is unknown, because stone and soil not including something close to reason.[28]

Likewise, Muhammad Abduh stated that the intention of al-ālamīn contained in the Surah al-Fatihah - as the Arabs say - is not shown in everything that exists, such as stone and earth, but in something that is intelligent or approaches that is intelligent like humans, animals, and plants.[29]

In another verse, the word al-âlamīn also has a meaning that has no implication for the meaning of the universe, namely in the letter Yusuf [12]: 104, letter [ād [38]: 87, al-Qalam [68]: 52, al-Takwir [81]: 27. The context discussed in these verses is that the Prophet Muhammad and the previous prophets did not ask for rewards for what they did to their people, in the form of calling for goodness and the book of the Koran as a warning to al ālamīn. In general, according to Ibn Abbas, the context of al-ālamīn contained in these verses is intended for the human race and jinn because what can understand and can be used as lessons only applies to these two creatures.[30]

From the explanation above the explanation shows that the term al-âlamīn does not indicate the meaning of the universe. Then what term in the Qur'an can indicate the purpose of the universe? The proper term for showing the universe is al-samāwa $\bar{a}$ wa al-ard wa mā baynahumā.[31] This term is mentioned in the Qur'an 20 times; al-Māidah and Șād three times, surat al-Dukhan twice, surat al-Hijr, Maryam, Țāhā, al-Furqān, al-Syu'arā ', al-Rūm, alSajdah, al-Ṣāffāt, al-Zuhruf, al-Aḥqāf, Qaf, and al-Nabā 'refer to it only once.[25]

One example of the verse contained in the term is in al-Māidah [5]: 17 and 18. The explanation in verse 17 is that God denies the Christian assumption that Jesus the son of Mary is God, this is answered by the word of God that God could have destroyed Jesus along with his mother and everyone on earth. If Jesus is God, he should be able to prevent that destruction. Allah hereby confirms that 'Isa al-Masih is also part of al-samāwāt wa al-ard wa 
$m \bar{a}$ baynahum $\bar{a}$. The explanation of verse 18 is that God denies the Jews (Uzair) and the Christians (Isa) as sons of God, this is evidenced by the persecution of their persecution if they make a mistake. So either Uzair or Isa are included in al-samāwāt wa al-ard wa mā baynahum $\bar{a}$ which Allah is free to do anything to his creatures.[32] So what is meant by alsamāwät wa al-ard wa mā baynahumā in this universe, both physical and non-physical, because the cues contained in the term are many different forms and natural laws.[28]

\subsection{The verses about the Creation of the Universe}

The selected verse is a verse that represents the creation of the universe, in fact there are eight verses, because some verses appear to be unsystematic and lack in explaining the procession of the universe's events, the author finally pursed the eight verses into just five verses; Surah Al-Anām verse: 73, Al-A'rāf verse: 54, Al-Anbiyā 'verse: 30 and Qaf verse: 38.

\subsubsection{Surat Al-Anam verse: 73}

In the verse it is explained that Allah created the heavens and the earth correctly (haq), meaning that it is just, that is to be the Creator, King or Owner, and Regulator for both and everything in it.[33] But Ibn 'Arabi in his interpretation put the word ārwāh (spirit) before heaven and jism (body) before the word earth. If interpreted in lafadz al-sam $\bar{a}$ ' language it means high and al-ardh means land or floor which is low position below. So the spirit is high because it will reach the hereafter, while the body is low because it only exists in the world. Both are treated by Allah fairly following His Essence.[34]

In another interpretation, Ibn Arabi explained that this verse discusses the rights of beings - that is, initial reason; the highest pen. The first thing that Allah creates is the intellects that govern a simple essence that is not material or in that material.[35]

\subsubsection{Surat Al-A’'rāf verse: 54}

In this verse Ibn 'Arabi again relies on the spirit and body on the word heaven and earth, according to him the meaning of six days in this verse is 6000 years, because according to the word of God: "Verily, one day with Allah is equal to 1000 years according to your calculations" (Al-Hajj / 22: 47), it means from the side of the creation of Adam until the time of the Prophet Muhammad. This duration starts at the beginning of the period of secrecy or closure until the beginning of the 'appearance' which is at the time of the prophetic door closing and the appearance of guardianship. As has been said that the time that has passed is like the condition where God created the heavens and the earth, because the beginning of the 'closure' with creation is the end of the 'appearance', and when the closure ends towards the visible then returns to the beginning of creation as already explained. To perfect the apparition the Prophet Muhammad came out to perfect the seven days. Thus the duration of the world is 7000 years.[34]

Some commentators state that Allah created the heavens and the earth in six days in terms of their estimates, not exist in existence, but according to Ibn 'Arabi this is wrong because heaven and earth were created by Allah in the six days that we know. But that day existed before heaven and earth were created, and the new day and night were the same as heaven and earth, in the sense that when the creation of heaven and earth were created day and night, that is why the term used by God in six days, not six days or nights. The beginning of creation on Sunday and finished on Friday some say Saturday.[35] 


\subsubsection{Surat Al-Anbiyā' verse: 30}

Ibn 'Arabi interpreted the sky as a spirit and the earth as a body. So the intention is to unite is once made from a drop of sperm that is nothing so that it looks one, then Allah separates in the sense of giving variation by giving limbs.[34]

In another interpretation, as Maḥmūd al-Ghurāb notes, there are two perspectives in understanding this verse. First, the purpose is unified in the verse is to distinguish. So between heaven and earth different materials or those produced by the earth such as metals, mineral water, plants, and animals. Second, heaven and earth are one like one body, then Allah divides them into seven levels, earth seven and heaven also seven.[35]

\subsubsection{Surat Qaf verse: 38}

Ibn 'Arabi interpreted the six days as six sides, but if it was interpreted birth. If it is regionally appointed, the sky is the spirit and the earth is the body. The six are divided into two parts. First, the so-called core collection; Jabarūt, Malakūt, and Mulk (kingdom). Second, what is called a collection is not core; Id âfiyyāt (supplementary, surrogate), Kammiyyāt (quantity) and Kayfiyyāt (quality).[34]

\section{Symbol Analysis}

\subsection{Introduction to Understanding Symbols}

Symbols are a very important element in the context of indirect speech, not face to face which is only limited to the text. Like al-Qur'an, poetry, and others. It is said that if the poem has no symbolic elements in it, it will dry without a spirit in it. In the Chinese tradition, it is precisely explained that the influence of symbols can make the delivery of texts that are few but meaningful solid, so the poet only needs a few words and for readers to interpret more broadly.[36]

The origin of the word symbol comes from the Greek symballein, which means "to throw together". In connection with this Gadamer stated that symbols are "something that makes it easy to recognize".[37] Whereas Subijantoro Atmosuwito states that a symbol is something that contains something invisible (invisible reality) that can only be reached by the inner eye.[38] Furthermore, Cassirer explained that what is meant by symbolic forms is every energy through which the content of the intellectual meaning is associated with signs that are captured by the senses and inwardly become a part of him.[39]

Thus, the symbol occupies a position that can bridge the outside world and the inner world or the world that cannot be seen with the naked eye and is accompanied by signs which if on target the desired meaning or expression will be conveyed through these signs. Concerning the problem of symbols, Imam Ghazali has the view that symbols are used to convey something of a different level.[40] Rumi also talked about this, that the symbols in poetry provide an opportunity for readers to enhance the contemplation of the beauty of the world to be a ladder going up to the contemplation of the beauty of God.[41] So the symbol for the Sufi is not just to convey a meaning or message, but also to get closer to God. 
In the Sufi tradition, the use of symbols refers to their esoteric traditions which emphasize deeper meaning. They are of the view that poetry is symbols of the truth and beauty of the human soul. Like other poetry traditions, Sufi literature also comes from the background, history and specific roots where Sufism grows based on the Qur'an, Hadith, Islamic history and also modified from the local culture. Al-Qushairy said that the birth of symbols in Sufism and their use in Sufi poetry were very closely related to their esoteric traditions. The symbols are assigned to protect from the knowledge of the people who are not in the same understanding as them.[42]

According to Rumi poetry must be able to reveal the intrinsic beauty and also aspects that surround the intrinsic beauty. So through simbollah, these aspects can be conveyed properly. According to Rumi, people cannot enter the fire of God without intermediaries, then imagery, for example, and class can help them feel how hot the fire is for people who approach the fire.[41] According to Javad Nurbakhsh, the symbols used by the Sufis are imagery and living images. Every symbol has a special interpretation that represents the reality and characteristics of the Eternal, Absolute or Beloved. The symbols also indicate the Sufi spiritual journey and meeting with Him. Usually the Sufis in support of this view, they use the hadith that uses symbolic condolences. Like: "Surely Allah has created Adam in His image (alā șüratihi). So the word suurah is a metaphor, which is not meant to be an essential image but is related to spiritual quality, sūrah is also used to symbolize the Names and Attributes of God.[43]

The symbolic imagery that is often used by Sufis is 'wine'. The meaning of wine, in general, describes spiritual knowledge. The wine shop is described as a place of divine love wine that is sold and drunk depicts mystical excitement and mystical drunkenness. Some reasons that make Sufis use the symbol of wine; because it can attract the attention of the reader, the function of wine that can 'cure', in this case, means to treat suffering. Rumi distinguishes the Sufi version of wine with the wine of ordinary people is if wine is a drink of Christians while for al-Hallaj is the drink of people who read Surat Yāsīn.[43]

No less important symbols are glass or cup and sharab (drinking). Glass or cup is described as the heart of a Sufi, then Sharab is known as passionate love and passion that knows no profit and loss. Sharab is also sometimes used to describe spiritual excitement or is also intended as emission from the disclosure of the divine nature which usually occurs when the Sufi is in a mortal position.[43] While Ibn 'Arabi explained that what was meant by the trophy was the heart of an āshiq (a yearning person). Because the heart of a yearner is dynamic depending on the color and type of drink poured by the Beloved.[23]

\subsection{Hermeneutics Symbol of Paul Ricoeur}

Ricoeur's interpretation model is more like Habernas, which maintains reflection for interpretation so that its hermeneutics works to reveal what is hidden behind the text. Thus, understanding of Ricoeur is revealing. Like Bultmann, Ricoeur's hermeneutic goal is sacred texts and symbolism in myths. If hermeneutics is tasked with understanding sacred texts and symbolism in myths, not only understanding what is contained in these texts but also understanding the world and life.

The idea of Ricoeur is very different from Gadamer who rejects the role of Cartesian reflection. Ricoeur sees it as something very important for hermeneutics. Understanding the text not only understands the meaning contained in the text but also reflects the meaning of our lives, shows the meaning outside the text and the meaning of the text shows philosophical reflection.[44] 
Ricoeur's hermeneutic circle consists of two basic things: First, believing that understanding means that faith is a presupposition of understanding. Second, understanding to believe means that interpretation helps modern people to believe.[44] So the position of faith for the first is as an introduction to understanding, just as we Muslims who have been given guidance in the form of faith so that we no longer need to criticize what is in the holy text of the Koran. Conversely, those who convert to Islam usually convert to Islam through reasoning and being critical of the sacred text, so as Ricoeur calls, they understand to believe.

According to Ricoeur symbols are all forms of expression that indicate eating more than one, in which there is a first meaning that refers back to himself and a second meaning that is never conveyed directly, this second meaning is the meaning symbolized. But hermeneutics as a theory of interpretation is not only directed at the double meanings contained in symbols but is demanded to be richer in giving meanings, especially spiritual meanings.[45]

\subsection{Analysis of the Interpretation of Ibn 'Arabi by Using Hermeneutics Paul Ricoeur}

Based on Ibn 'Arabi's interpretation of the verses of the concept of the creation of nature, from the four verses quoted and used as standardization as verses that represent the creation of nature, Ibn' Arabi precisely does not explicitly explain the chronology or stages of the natural creative process. Even Ibn 'Arabi used metaphors in heaven and earth; that the heavens as a spirit and the earth as a body, and this happens in almost every verse. The connection with the creation of the earth which was carried out for six days Ibn 'Arabi precisely explained six days as six thousand years which later alluded to the age of the world to seven thousand years. In another interpretation, Ibn 'Arabi even explained that the six in the verse is the meaning of the six parts that explain a material. So the material is divided into two; First, the essence of the core is divided into three; Jabarūt, Malakūt, and Mulk. Second, something that is not core; I verses that explain that the heavens and the earth were united were interpreted by Ibn 'Arabi by the analogy of humans, that initially, humans were nutfah in the form of only one drop, then another body appeared.

In the hermeneutic circle, Paul Ricoeur that what becomes presupposition is new faith then understands or is also behind understanding for faith. So the symbols offered by Ibn 'Arabi in their interpretation are very closely related to eschatology which can make our faith increase. As expressed by Ricoeur that there must be a reflection in understanding, then what is said by Ibn 'Arabi that we contemplate and look for its meaning in life.

\section{Conclusions}

Ibn 'Arabi's interpretation of the concept of natural creation does not explain in detail the chronology and process. It explains the eschatological symbols or metaphors such as souls and bodies. So basically Ibn Arabi saw what was born contained in these verses, precisely interpreting that is nothing but meaning outside of it, but still holding fast to the meaning of birth. Just as the sky is meant as a spirit and the earth is interpreted as a body, this is because the nature of the high sky is the same as a spirit that is subtle and noble, then a mortal body is likened to the earth which is positioned below. 
Acknowledgements. This research supported by The Graduate School of Islamic Studies UIN Syarif Hidayatullah.

\section{References}

[1] A. A. H. dan B. A. Saebani, Filsafat Umum dari Mitologi sampai Teofilosofi. Bandung: CV. Pustaka Setia, 2008.

[2] W. C. Chittick, The Sufi Path of Knowledge: Ibn al-Arabi's Metaphysics of Imagination. New York: Suny Press, 1989

[3] K. A. Noor, Ibn al-'Arabi Wahdat al-Wujud dalam Perdebatan. Jakarta: Paramadina, 1995.

[4] E. S. Waterhouse, "The Mystical Philosophy of Muhyid Din-Ibnu 'Arabi. By A. E. Affifi. (London: Cambridge University Press. 1939. Pp. xxi + 213. Price 12s. 6d.)," Philosophy, 1941.

[5] J. A. A. al-R. Al-Suyuthi, Al-Itqān fi Ulum al-Qur'ān. Cairo: Maktaba wa matba'a al-Masyhad alHusayni, 1967.

[6] I. Shalah, Fatāwā. Cairo: Idārā Thabā’a al-Muniriyya, 1348.

[7] Syarifuddin, "'Menimbang otoritas sufi dalam menafsirkan al-Qur'an," Stud. Agama dan Masy., 2004.

[8] M. S. Al-Jilliand, al-Imām Ibn Taymiyyah wa Mauqifuhu min Qadiyyat al-Ta'wīl,. Jeddah: Maktabah 'Ukaz, 1983.

[9] A.-S. A.-S. Zaghlul, Ittijāhāat al-Fikriyyah Fi al-Tafsīr. Alexandria: Maktabah al-Āmāh Li al-Kitāb, 1977.

[10] M. A. Sells, Early Islamic Mysticism. New Jersey: Paulist Press.

[11] M. H. Al-Dhahabi, Tafsìr Wa al-Mufassirūn. Cairo: Maktabah Wahabiyyah.

[12] R. A. Nicholsom, Studies in Islamic Mysticism. London: Curzon Press, 2005.

[13] S. Z. Haq, “Hermeneutika Sufistik: Telaah Epistemologi Takwil Ibn 'Arabi,”, Tibyan, pp. 1-25, 2019.

[14] O. A. Bakr, "'The Symbolic Function of Methapor in Medieval Sufi Poetry: The Case of Alif," Joernal Comp. Poet., pp. 40-57, 1992.

[15] A. Schimmel, Mystical Dimensions of Islam. North Calorina: The University of North Carolina Press, 1975

[16] Al-Ghazali, Fadā'ih al-Batiniyyah. Beirut: Maktabat al-'Asriyyah, 2011.

[17] M. Campanini, The Qur'an: The Basics. London and New York: Routledge, 2007.

[18] A. Salahudin, Kontruksi Epistemologi Tasawuf dalam Tarekat Qādiriyyah Naqshabandiyyah Pondok Pesantren Suryalaya Membangun Peradaban Dunia. Suryalaya: Mawaddah warohmah Press, 2011.

[19] S. S. H. Rizvi, “"The Existential Breath of al-Rahmān and the Munificent Grace of al-rahim: The Tafsi Surat al-Fātihah of Jāmi and the School of Ibn 'Arabi,'” J. Qur'anic Stud., pp. 58-87, 2006.

[20] C. W. Ernst, "Nasr Hamid Abu Zayd on Ibn 'Arabi," J. Muhyiddin Ibn 'Arabi Soc., 2010.

[21] K. Z. Sands, Sufi Commentaries on the Qur'än in Classical Islam. New York: Routledge, 2006.

[22] A.-H. bin A. Al-Muhasibi, al-'Aql wa Fahm al-Qur'ān. Beirut: Dār al-Fikr, 1971.

[23] M. Ibn 'Arabi, Al-Futūhāt al-Makkiyyah. Beirut: Dār al-Iḥyā al-Turāth al-'Arabī, 2010.

[24] H. Wehr, A Dictionary of Modern Written Arabic,. Beirut and London, 1974.

[25] M. F. A. Al-Baqiy, al-Mu'jam al-Mufahras li Alfaz al-Qur'ān al-Karīm. Beirut: Dār al-Fikr, 1987.

[26] Al-Juwayni, Lam' Al-Adillah Fi Qawa'id Aqa'id Ahl Al-Sunnah wa Al-Jama'ah. Cairo: Dār alMișriyyāt, 1965.

[27] J. Saliba, al-Mu'jam al-Falsafiy. Beirut: Dār al-Kitāb al-Lubnaniy, 1973.

[28] S. Zar, Konsep Penciptaan Alam dalam Pemikiran Islam, Sains dan Al-Qur'an. Jakarta: PT. RajaGrafindo Persada, 1994.

[29] M. R. Ridha, Tafsīr al-Qur'ān al-Hakīm (Tafsīr al-Manār). Beirut: Dār al-Fikr.

[30] I. Abbas, Tanwīr al-Miqbas min Tafsīr Ibn 'Abbās. Beirut: Dār al-Fikr.

[31] H. Bahreisy, Kamus Islam Menurut Qur'an dan Hadits. Surabaya: Galundi Jaya. 
[32] Al-Thabathaba'iy, al-Mīzān fi al-Tafsìr al-Qur'ān. Beirut: Mu'assisāt al-A'lamiy li al-Mațbū'àt, 1983.

[33] I. Kathir, Tafsīr al-Qur'ān al- 'Azīm. Beirut: Dār al-Kutub al-'Ilmiyyah, 1998.

[34] M. Ibn 'Arabi, Tafsir Ibn 'Arabi.

[35] M. Ibn 'Arabi, Raḥmah min al-Raḥmān fi Tafsīr wa Ishārāt al-Qur'ān. Damaskus, 1979.

[36] A. W. HM, Tasawuf yang Tertindas: Kajian Hermeneutik terhadap Karya-Karya Hamzah Fansuri. Jakarta: Paramadina, 2011.

[37] H. G. Gadamer, Truth and Method. New York: Crossroad Publishing Co, 1976.

[38] S. Atmosuwito, Perihal Sastra dan Religiusitas dalam Sastra. Bandung: CV. Sinar Baru, 1989.

[39] E. Cassirer, Manusia dan Kebudayaan: Sebuah Esai tentang Manusia. Jakarta: PT. Gramedia, 1990.

[40] W. Gairdner, al-Ghazali’s Misykāt al-Anwār. New Delhi: Kitab Bhavan, 1981.

[41] A. Schimmel, “"The Symbolical Language of Mawlana Jalal al-Din Rumi,"” Stud. Islam, pp. 2641, 1964.

[42] A. A.-W. Al-Taftazani, Sufi dari Zaman ke Zaman. Bandung: Pustaka, 1985.

[43] J. Nurbakhsh, Sufi Symbolism. London: Khaniqahi-Nikmatullah Publications, 1984.

[44] B. F. Hardiman, Seni Memahami Hermeneutik dari Schleiermacher sampai Derrida. Yogyakarta: PT. Kanisius, 2015.

[45] J. B. and P. R. Thompson, Hermeneutics and the Human Sciences. Cambridge: Cambridge University Press, 1990. 
